\title{
Cost-benefit analysis of rehabilitation and opening new cultivation land for tangerine cv Madu impacted by volcanic ash fallout of Mount Sinabung, North Sumatra, Indonesia
}

\author{
LYLI MUFIDAH", AGUS SUGIYATNO, M. TAUFIQ RATULE \\ Indonesian Citrus and Subtropical Fruits Research Institute (ICSFRI). Jl. Raya Tlekung, No. 1, Batu - East Java, Indonesia. Tel: +62-341-592683, Fax: \\ +62-341-593047. "email: lyli.mufidah@gmail.com
}

Manuscript received: 12 March 2017. Revision accepted: 3 September 2017.

\begin{abstract}
Mufidah L, Sugiyatno A, Ratule MT. 2017. Short Communication: Cost-benefit analysis of rehabilitation and opening new cultivation land for tangerine cv Madu impacted by volcanic ash fallout of Mount Sinabung, North Sumatra, Indonesia. Nusantara Bioscience 9: 339-345. Indonesian tangerine plants which have diverse varieties possess the adaptability from lowlands to highlands in the tropical region. Some of the tangerine production centers in Indonesia, such as Karo, Mandailing Natal, Dairi, Malang, Batu, and Bali are located in the volcano path which is prone to eruption. The eruption of Mount Sinabung in 2013 and 2014 had caused damage to the local tangerine cv Madu cultivation which was estimated to reach more than 476 billion rupiahs. The eruption affected a cultivation area of 7.202,89 ha and has been predicted to be one of the factors that caused the decline of North Sumatra's contribution to tangerine production. Therefore, this paper has tried: (i) to analyze the financial feasibility of rehabilitating tangerine cv Madu cultivation located in between 7-10 km radius of the eruption center (zone 1) and in between 5-7 km radius of the eruption center (zone 2), and (ii) to consider the option of opening up a new tangerine cultivation land.The results showed that the BCR for the immediate rehabilitation of zones 1 and 2 were 3.33 and 2, respectively. Thus, the rehabilitation scheme was feasible to be implemented and can reduce the damage and losses suffered by farmers. On the other hand, the opening of new land still takes approximately three years to be productive. The BCRof the option of opening new land within that period of time was 0.47 , which is lower compared with that of the rehabilitation of zones 1 and 2 (2.61 and 2.57, respectively).This study was intended as an initial guidance for making decisions and determining the potential benefit to be gained and the losses that can be avoided. This study also gave an overview of the budget that should be prepared. In conclusion, we recommended the farmers to carry out the rehabilitation over opening up new cultivation land.
\end{abstract}

Keywords: cost-benefit analysis, tangerine cv Madu rehabilitation, volcanic ash

\section{INTRODUCTION}

Indonesian tangerine and mandarin fruits has diverse variety and unique characteristics and have become the most widely consumed fruits by Indonesian households (BPS 2010). The market opportunity for tangerine is wide open, as the Indonesian middle-class increase and the population become more aware of the nutritional importance of fruits for their daily consumption. The government policy, Permendag (No.70/M$\mathrm{DAG} / \mathrm{PER} / 12 / 2013$ ), that gives access to local tangerines to enter the modern retail market and the economic criteria fulfillment have made this crop cultivation worthy to consider.

Tangerine has a wide adaptability, ranging from lowlands to highlands of tropical climates. Altitude (elevation) reflects the temperature of an area. Every plant variety will grow and produce optimally when grown at the appropriate altitude with customized cultivation techniques of planting (Ladaniya 2008). In 2010-2014, Indonesian tangerine and mandarin centers had experienced a change in their contribution compared to 2005-2009. In 2005-2009 the tangerine and mandarin centers contribution were as follows: North Sumatera $40.30 \%$, East Java $13.80 \%$, West Kalimantan $7.50 \%$ ， West Sulawesi $5.80 \%$ ， South
Kalimantan $5.40 \%$ and others $27.20 \%$. In $2010-2014$, the contribution of the production centers were as follows: North Sumatera 29.82\%, East Java 23.89\%, West Kalimantan 9.04\%, South Kalimantan 6.56\%, Bali 6.64\% and others $24.05 \%$. The tangerine and mandarin production in North Sumatera was supported by five main regions, Karo Regency (59.31\%), Simalungun Regency (16.22\%), Dairi Regency (10.41\%), Tapanuli Utara Regency $(5.12 \%)$, Mandailing Natal Regency (3.37\%), and others (5.58\%). In East Java and West Kalimantan, the production was supported by five and four regions, respectively. In East Java, those regions are Banyuwangi (48.08\%), Jember (25.98\%), Malang $(3.77 \%)$, Ponorogo $(4.40 \%)$, Batu $(2.32 \%)$ and others $(15.45 \%)$. In West Kalimantan, the production areas are Sambas Regency $(78.66 \%)$, Singkawang City (11.51\%), Bengkayang Regency (6.68\%), Pontianak Regency (1.95\%) and others (1.20\%) (BPS 2010; Pusdatin 2015)

The decline in tangerine and mandarin production in North Sumatra, in which the Karo Regency suffer the biggest plunge, needs to be observed because the decline reached 10.48\%. Between 2013-2014, the area suffered from volcanic eruptions in which volcanic ash severely coverd many crops cultivation including the tangerine $\mathrm{cv}$ Madu. The particular characteristic of tangerine cv Madu is 
its cultivation in the highlands, while other tangerines, in general, are cultivated in the lowlands. From the maintenance point of view, one of the primary concerned in tangerine cultivation, is the pest management of fruit fly. The ash fallout that has corrosive, abrasive and conductive properties can potentially damage the agricultural system. Therefore, the impact of volcanic ash fallout needs to be understood to minimize the damage (Wilson et al. 2012; Craig et al. 2016). Mount Sinabung itself, in the beginning, was not included as an active volcano because of its last eruption that occurred in 1600 , but after the earthquake and tsunami in Aceh in 2014, the activity of the volcano has been changing.

The tangerine cv Madu cultivation in Karo Regency suffered a tremendous loss of more than 476 billion rupiahs because of the Mount Sinabung's eruption. In addition, the five primary tangerine production areas have been under constant threat of volcanic eruption impact because Indonesia is located along the ring of fire, an area occupied by a string of volcanoes and high seismic activity along the edges of the Pacific Ocean (Bangun et al. 2014). Considering the significant impact of the volcanic eruption and its potential to inflict damage to tangerine cultivation in the future, this paper aimed to analyze the financial feasibility of: (i) the Tangerine cv Madu Rehabilitation in Karo that damaged by the volcanic ash fallout of the Mount Sinabung eruption and (ii) the option of opening new cultivation land, by using the cost-benefit analysis (Shreve et al. 2014; Asa and Tobias 2015; Mechler 2016). We hope that this study can serve as an initial guidance for making decisions and determining the potential benefit to be gained and losses that can be avoided, as well as to providing an overview of the budget that should be prepared.

\section{MATERIALS AND METHODS}

\section{Study area}

The study was conducted in Mount Sinabung, Karo District, North Sumatra, Indonesia, includes Simpang Empat Sub-district which is situated in between 7-10 km radius of the eruption center of Mount Sinabung, henceforth referred to as zone 1; and Naman Teran Subdistrict which is located in between $5-7 \mathrm{~km}$ radius of the eruption center, henceforth referred to as zone 2 . Both subdistricts are situated in Karo regency area and have been previously described by Sugiyatno and Nainglon (2014). The two zones showed the prospect to be rehabilitated. The research and the financial analysis of these areas were carried out from February to March 2014. Meanwhile, the newly open cultivation area is located in Merek Sub-district of Karo District (Figure 1). The area was expected to be safe and suitable for tangerine cultivation. The technician surveys were conducted in 2014 and 2017.
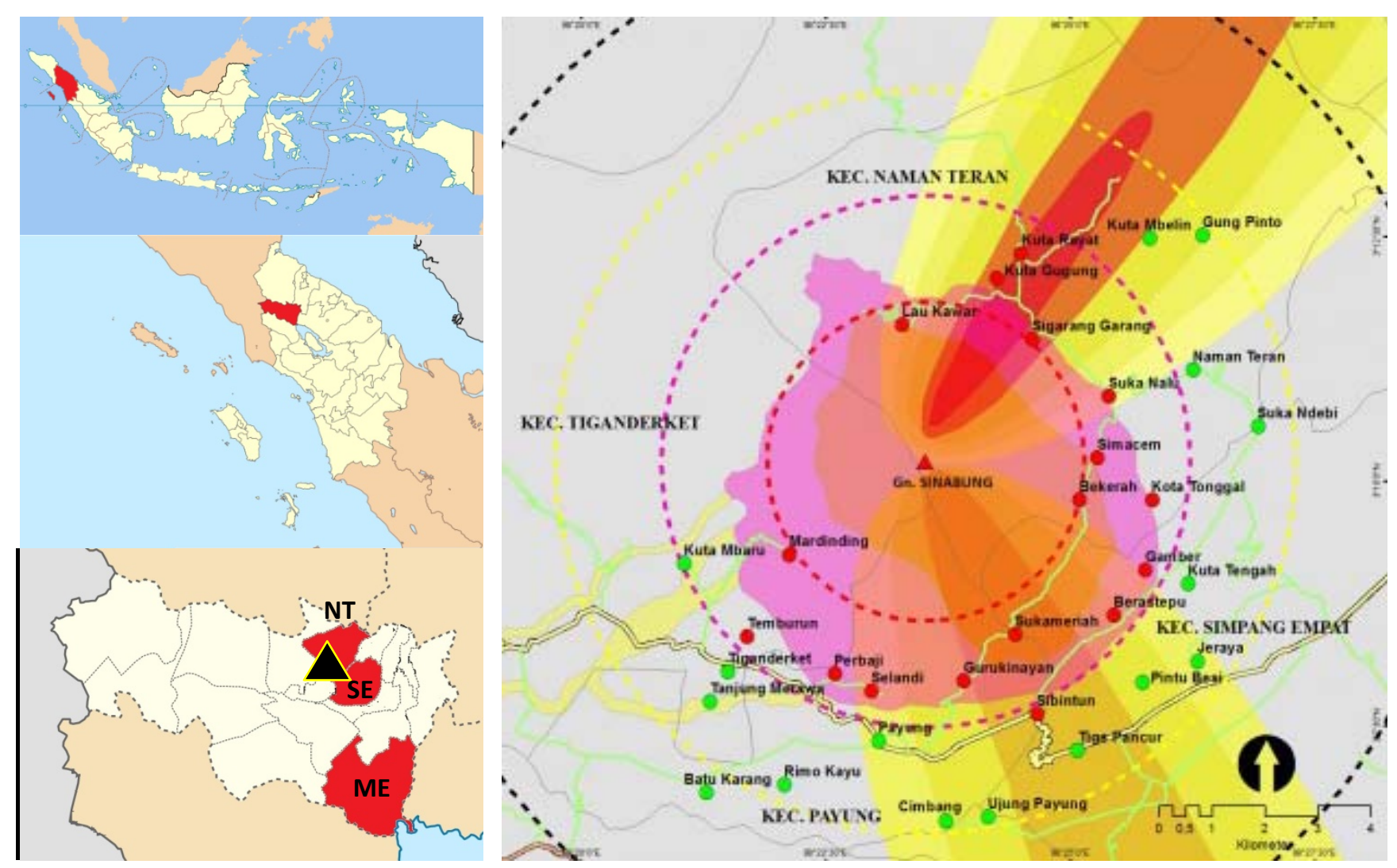

Figure 1. Research location maps in Province of North Sumatra, Indonesia. Location of Mount Sinabung (indicated as black triangle), Naman Teran Sub-district (NT), Simpang Empat Sub-district (SE), and Merek Sub-district (ME). Maps of Mount Sinabung eruption impact on February 1, 2014 that continues until today (right). The center of the concentric circles is the eruption center of Mount Sinabung. 


\section{Procedures}

This research used secondary data obtained from Sugiyatno and Nainggolan (2014) research, Department of Agriculture, Province of North Sumatera (2014) and BPS (2016). The damaged cultivation areas were classified and selected for zones $1( \pm 5.972,60 \mathrm{ha})$ and $2( \pm 293.08 \mathrm{ha})$, where rehabilitation was still a viable option. The calculation of the costs and benefits was done in Indonesian Rupiah (IDR). The advantage of the rehabilitation was quantified by using the average losses that could be saved. The rehabilitation in this research was defined as an attempt to repair, restore and improve the land condition of tangerine cv Madu that damaged by Sinabung Mountain eruption. The rehabilitation was intended to optimize the land function as an element of production. The rehabilitation activities in zone 1 and zone 2 were conducted differentially according to the damage level of each zone. In the newly open cultivation land located in Merek Sub-district which was outside of the zone 1 and 2, the activities consisted of land acquisition, land preparation, and maintenance of the tangerine trees until ready to produce.

\section{Data analysis}

The cost-benefit analysis allows decision makers to appraise projects in a comparable manner and consistency. Cost-benefit analysis can be used: (i) to provide information for decision-makers, whether the rehabilitation project investment is a feasible solution (Djukic et al. 2016), and (ii) to weigh which one of the two options, i.e., the rehabilitation or the option of opening a new cultivation land, is more feasible (Salisu et al. 2012; Lekh and Virendra 2014). Some assumptions need to be made to determine the input data (Asa and Tobias 2015; Andre et al. 2016). In this case, three options and assumptions were considered as described in Table 1.

The method that was chosen for the data analysis was the benefit-cost ratio (BCR). It involved summing up the total discounted benefits for a project over its entire duration and dividing it over the total discounted costs of the project, with the following formula:

\section{$\mathrm{BCR}=\quad\left[\sum \mathrm{B}_{\mathrm{i}} /(1+\mathrm{d})^{\mathrm{i}}\right]$ summed over 0 to $\mathrm{n}$ years $\left[\sum \mathrm{C}_{\mathrm{i}} /(1+\mathrm{d})^{\mathrm{i}}\right]$} years

$\mathrm{Bi}=$ benefit of the project in year $\mathrm{i}$, where $\mathrm{i}=0$ to $\mathrm{n}$

$\mathrm{Ci}=$ cost of the project in year $\mathrm{i}$, where $\mathrm{i}=0$ to $n$ years

$\mathrm{n}=$ the year duration that was taken into account in the project (time of period)

$\mathrm{d}=$ discount rate

\section{Time period}

The rehabilitation scheme was evaluated in two timepoints, firstly, at one year after the rehabilitation, and secondly, at three years after the rehabilitation.

\section{Discount rate}

The discount rate based on the Ramsey formula (1928) for the Social Rate of Time Preference (SRTP) for Indonesia, which was $6.1 \%$. SRTP was used because the project had been aimed at the government which was the measure of society's willingness to postpone private consumption now in order to consume later (Zhuang et al. 2007; Halicioglu and Karatas 2011). The SRTP approach was based on the framework that the main goal of economic prosperity is to maximize the community benefits (Moore et al. 2013).

\section{The interpretation of the BCR value}

If the $\mathrm{BCR} \geq 1$ (project received); $\mathrm{BCR}<1$ (project rejected) and $\mathrm{BCR}=1$ (whether a project is implemented or not implemented has no effect); while, to determine which project was more feasible, a comparison was made among the BCR values. Upon comparing multiple schemes, the options with the highest BCR are preferred and deem feasible.

The data of cost (Table 2) refers to the rehabilitation activities and the new cultivation land opening. Data of tangerine cv Madu maintenance for 10 and 3 years old trees are shown in Table 3.

Table 1. The comparison of the cost and benefit of three scenarios

\begin{tabular}{ll}
\hline Options & Costs/Issues \\
\hline Do nothing & $\begin{array}{l}\text { Tangerine cv Madu is facing a decline in production that has been } \\
\text { estimated to reach 30\% and a loss cost of Rp. 476.109.849.600,-- }\end{array}$ \\
$\begin{array}{l}\text { Tangerine cv Madu } \\
\text { rehabilitation for zones 1 } \\
\text { and 2 }\end{array}$ & $\begin{array}{l}\text { Requires rehabilitation cost. } \\
\text { It does not require time to wait because the crop age is in the } \\
\text { productive age (ranging up to10 years old). }\end{array}$ \\
$\begin{array}{l}\text { Opening up new land for } \\
\text { tangerine cv Madu } \\
\text { cultivation }\end{array}$ & $\begin{array}{l}\text { The cost of finding suitable land for cultivation and land clearing. } \\
\text { Need to wait for three years for the tangerine trees in the new } \\
\text { cultivation area to bear fruit (harvest). } \\
\text { The loss of tangerine cv Madu that was left because of volcanic } \\
\text { ash fallout }\end{array}$
\end{tabular}

\section{Benefits}

No benefit will be gained. However, it will cost nothing for rehabilitation and open up new land.

Productive crops can be saved, thereby, reducing the loss from crop failures.

The cultivation area will be safer. 
Table 2. Preliminary analysis of costs for the rehabilitation of tangerine cv Madu affected by volcanic ash fallout for 1 hectare (assumption $1 \mathrm{ha}=620$ tree)

\begin{tabular}{|c|c|c|c|c|c|}
\hline Areas & Rehabilitation Activity & Volume & $\begin{array}{c}\text { Unit price } \\
\text { (Rp.) }\end{array}$ & $\begin{array}{c}\text { Amount } \\
\text { (Rp.) }\end{array}$ & $\begin{array}{l}\text { Total } \\
\text { (Rp.) }\end{array}$ \\
\hline \multirow[t]{17}{*}{ Zone 1} & & & & & $19,841,000$ \\
\hline & High-pressure spraying & & & & \\
\hline & Water & 17501 & 72 & 126,000 & \\
\hline & Automatic power sprayer & 1 & $4,000,000$ & $4,000,000$ & \\
\hline & Hose & 1 & 550,000 & 550,000 & \\
\hline & Workers needed (smd) & 4 & 55,000 & 220,000 & \\
\hline & Prune the dry branches & & & & \\
\hline & Pruning shears (Prohex) & 2 & 82,500 & 165,000 & \\
\hline & Workers needed (smd) & 2 & 55,000 & 110,000 & \\
\hline & Weed control $(4 \mathrm{x})$ & & & & \\
\hline & Workers needed (smd) & 14 & 55,000 & 770,000 & \\
\hline & $\begin{array}{l}\text { Cultivate the soil under the plant canopy (mixing the } \\
\text { volcanic ash with the soil and applying manure at a dose } \\
\text { of } 30-40 \mathrm{~kg} \text { ) }\end{array}$ & & & & \\
\hline & (1 sack of manure $\pm @ 30-40$ kg) & 620 & 11,000 & $6,820,000$ & \\
\hline & Applying NPK fertilizers at a dose of $1 \mathrm{~kg} / \mathrm{plant} /$ year & & & & \\
\hline & NPK fertilizers & 620 & 10,000 & $6,200,000$ & \\
\hline & Controlling fruit flies & & & & \\
\hline & Trap & 10 & 88,000 & 880,000 & \\
\hline \multirow[t]{16}{*}{ Zone 2} & & & & & $25,686,000$ \\
\hline & High-pressure spraying & & & & \\
\hline & Water & 17501 & 72 & 126,000 & \\
\hline & Automatic power sprayer & 1 & $4,000,000$ & $4,000,000$ & \\
\hline & Hose & 1 & 550,000 & 550,000 & \\
\hline & Workers needed (smd) & 4 & 55,000 & 220,000 & \\
\hline & Prune the dry branches & & & & \\
\hline & Pruning shears ( Prohex) & 2 & 82,500 & 165,000 & \\
\hline & Workers needed (smd) & 2 & 55,000 & 110,000 & \\
\hline & Applying NPK fertilizer $2 \mathrm{~kg} / \mathrm{rod} /$ year (twice a year) & & & & \\
\hline & Applying manure $30-40 \mathrm{~kg} /$ plant & & & & \\
\hline & NPK fertilizer & 1240 & 10,000 & $12,400,000$ & \\
\hline & (1 sack of manure $\pm @ 30-40$ kg) & 620 & 11,000 & $6,820,000$ & \\
\hline & Controlling insecticide & & & & \\
\hline & Abamectin & 2 & 125,000 & 250,000 & \\
\hline & Workers needed (smd) & 3 & 55,000 & 165,000 & \\
\hline
\end{tabular}

Source: Sugiyatno and Nainggolan (2014); Balitjestro technician survey results $(2014,2017)$

\section{RESULTS AND DISCUSSION}

\section{Results}

The BCR for the rehabilitation of tangerine cv Madu plantation for one year are 3.33 for zone 1 , and 2 for zone 2 , respectively, with a total benefit value and total cost value as shown in Table 6 . The total areas expected to be saved were $6,265.68$ ha, consisting of 5,792.6 ha in the zone 1 and 293.08 ha in the zone 2. These results illustrate that the rehabilitation project could be implemented because it could minimize the impact of the farmer's loss by $86 \%$. On the other hand, for the three-year period, the BCR values were 2.61 and 2.57 in zones 1 and 2, respectively, taking into account the maintenance cost for 10 -year-old tangerine cv Madu (according to the observation result), the selling price of $\mathrm{Rp}$. $7.946,-/ \mathrm{kg}$ (based on the average price, BPS 2010), and the average production of $50 \mathrm{~kg}$ per tree. The BCR value for rehabilitation project within one-year period (direct handling) means that the cost to rehabilitate 1 unit gives a benefit of 3.23 (for zone 1) and 2 (for zone 2). In the threeyear period, the cost to rehabilitate 1 unit gives a benefit of 2.62 and 2.57 for zone 1 and 2, respectively. Overall, the BCR exceeded 1 indicating that the benefit of the rehabilitation outweighs the expense costs.

The BCR for opening up a new land for the cultivation of the tangerine was 0.47 , which means that the cost of 1 unit produced would have a benefit of only 0.47 for the three-year period. The total area of the newly opened land for the tangerine cultivation was consistent with the area that was potentially rehabilitated from the volcanic ash fallout impact. Three years after the opening, the trees bear fruit with an average production of $25 \mathrm{~kg}$ per tree. The total of the benefit value and the total cost are shown in Table 7. 
The obtained benefit for the three-year period after discounted was smaller than the expense costs. Based on this result, for the three-year term, the more feasible project is the rehabilitation of tangerine cv Madu in zones 1 and 2. The rehabilitation project gives a positive impact on the farmers in the first three years post-eruption.

\section{Discussion}

The BCR values recommended the rehabilitation for both zones 1 and 2, whereas the BCR analysis gave a different suggestion for the option of rehabilitation and the option of opening up new cultivation land. This difference could be caused by the fact that (i) the tangerine cv Madu cultivation land affected by the mount Sinabung eruption had still been producing, thus, saving the land means saving losses from the harvest failure, while the scheme of opening up new land means throwing away the chance of harvesting from the affected land; (ii) it takes approximately three years in order to reap the results in the case of opening up new land, and (iii) the differences in plants ages between the tangerine cv Madu that affected by the Sinabung mountain eruption (10 years old plants) and the tangerine in the new cultivation land (3 years old plants), means that they will have different productivity (IPB 2013). Despite the quantitative analyses mentioned above, not all the benefits/advantages and costs can be expressed in number, for example, the safe area for opening up the new land for cultivation and the decrease in tangerine supplies without rehabilitation projects.

The decrease in tangerine supplies due to production issues in North Sumatera might be among the causes of the increased in tangerine and mandarin import in 2014. The limited data on the loss cost in each zone also needed to be considered because the use of the average value could affect the sharpness of the analysis. This is seen from the BCR value of the rehabilitation projects within the three year period that is smaller than that of the direct handling. Furthermore, the land availability becomes an issue that should be noticed. In the long run, the rehabilitation project can provide a sustained benefit (Burnett et al. 2017) considering the limitation of available citrus-cultivation land that was estimated to be around 5.715.198 ha (Mufidah et al. 2016).
Table 3. The maintenance cost of 1 ha tangerine cv Madu aged 10 years (assumption $1 \mathrm{ha}=620$ tree)

\begin{tabular}{|c|c|c|c|}
\hline Item description & Vol & $\begin{array}{r}\text { Unit } \\
\text { price } \\
\text { (Rp) }\end{array}$ & $\begin{array}{c}\text { Amount } \\
\text { (Rp) }\end{array}$ \\
\hline \multicolumn{4}{|l|}{ Production facilities } \\
\hline Manure 1 sack/hole & 620 & 11,000 & $6,820,000$ \\
\hline NPK fertilizer (5kg/plant) & 3100 & 10,000 & $31,000,000$ \\
\hline Urea $(\mathrm{kg})$ & 250 & 2,200 & 550,000 \\
\hline Antracol Fungicide (kg) & 20 & 107,800 & $2,156,000$ \\
\hline Folicur Fungicide (kg) & 14 & 132,000 & $1,848,000$ \\
\hline Winder Insecticide (kg) & 39 & 66,000 & $2,574,000$ \\
\hline Gandasil D foliar fertilizer $(\mathrm{kg})$ & 8 & 44,000 & 352,000 \\
\hline $\begin{array}{l}\text { ZA fertilizer }(1 \mathrm{~kg} / \text { plant }) 1 \text { time per } \\
\text { year }\end{array}$ & 620 & 1540 & 954800 \\
\hline TSP fertilizer ( $1 \mathrm{~kg} /$ plant $)$ & 620 & 3650 & 2263000 \\
\hline Mg fertilizer (1 kg/plant) & 620 & 650 & 403000 \\
\hline \multicolumn{4}{|l|}{ Workers needed (smd) } \\
\hline Digging and filling planting hole & 620 & 5,500 & $3,410,000$ \\
\hline Carry and spreading manure & 620 & 1,100 & 682,000 \\
\hline Planting & 620 & 1,100 & 682,000 \\
\hline Pruning, $7 \mathrm{x} /$ month ( 2 workers) & 168 & 55,000 & $9,240,000$ \\
\hline $\begin{array}{l}\text { Pest and disease control }(4 \mathrm{x} / \\
\text { month) }(2 \text { workers })\end{array}$ & 96 & 55,000 & $5,280,000$ \\
\hline Weeding (12x/year) ( 2 workers $)$ & 480 & 55,000 & $26,400,000$ \\
\hline $\begin{array}{l}\text { Applying fertilizer ( } 3 \mathrm{x} / \text { year) }(2 \\
\text { workers) }\end{array}$ & 6 & 55,000 & 330,000 \\
\hline $\begin{array}{l}\text { Irrigating } 4 \mathrm{x} / \mathrm{month} \text { during the dry } \\
\text { season ( } 3 \text { months) ( } 2 \text { workers) }\end{array}$ & 24 & 55,000 & $1,320,000$ \\
\hline
\end{tabular}

Total cost

$65,364,000$
Table 4. Cost of opening new tangerine cv Madu cultivation land (assumption $1 \mathrm{ha}=620$ tree)

\begin{tabular}{|c|c|c|c|}
\hline Item description & Vol & $\begin{array}{r}\text { Unit } \\
\text { price } \\
\text { (Rp) }\end{array}$ & $\begin{array}{c}\text { Amount } \\
\text { (Rp) }\end{array}$ \\
\hline \multicolumn{4}{|l|}{ Land Cost (ha/yr) } \\
\hline Land lease & 1 & $2,500,000$ & $2,500,000$ \\
\hline \multicolumn{4}{|l|}{ Production facilities } \\
\hline Manure 1 sack/hole & 620 & 11,000 & $6,820,000$ \\
\hline Seeds & 645 & 9,350 & $6,030,750$ \\
\hline NPK fertilizer $(\mathrm{kg})$ & 250 & 10,000 & $2,500,000$ \\
\hline Urea (kg) & 250 & 2,200 & 550,000 \\
\hline Antracol Fungicide (kg) & 20 & 107,800 & $2,156,000$ \\
\hline Folicur Fungicide (kg) & 14 & 132,000 & $1,848,000$ \\
\hline Winder Insecticide (kg) & 39 & 66,000 & $2,574,000$ \\
\hline Gandasil D foliar fertilizer $(\mathrm{kg})$ & 8 & 44,000 & 352,000 \\
\hline \multicolumn{4}{|l|}{ Equipment and supporting materials } \\
\hline Plant stake & 620 & 165 & 102,300 \\
\hline Plastic hose & 1 & 550,000 & 550,000 \\
\hline Semi-automatic sprayer & 1 & 550,000 & 550,000 \\
\hline Pruning shears (Prohex) & 1 & 82,500 & 82,500 \\
\hline \multicolumn{4}{|l|}{ Workers needed (smd) } \\
\hline Digging and filling planting hole & 620 & 5,500 & $3,410,000$ \\
\hline Carryingand spreading manure & 620 & 1,100 & 682,000 \\
\hline Planting & 620 & 1,100 & 682,000 \\
\hline Seed delivery & 1 & $1,100,000$ & $1,100,000$ \\
\hline Pest and disease control (1x/week) & 96 & 55,000 & $5,280,000$ \\
\hline Weeding (1x/month) & 36 & 55,000 & $1,980,000$ \\
\hline Applying fertilizer ( $1 \mathrm{x} / 3$ month) & 12 & 55,000 & 660,000 \\
\hline Irrigating $2 \mathrm{x} /$ month during the dry & 48 & 55,000 & $2,640,000$ \\
\hline
\end{tabular}


Table 5. The maintenance cost of 1 ha tangerine cv Madu plantation aged $1-3$ years (assumption $1 \mathrm{ha}=620$ tree)

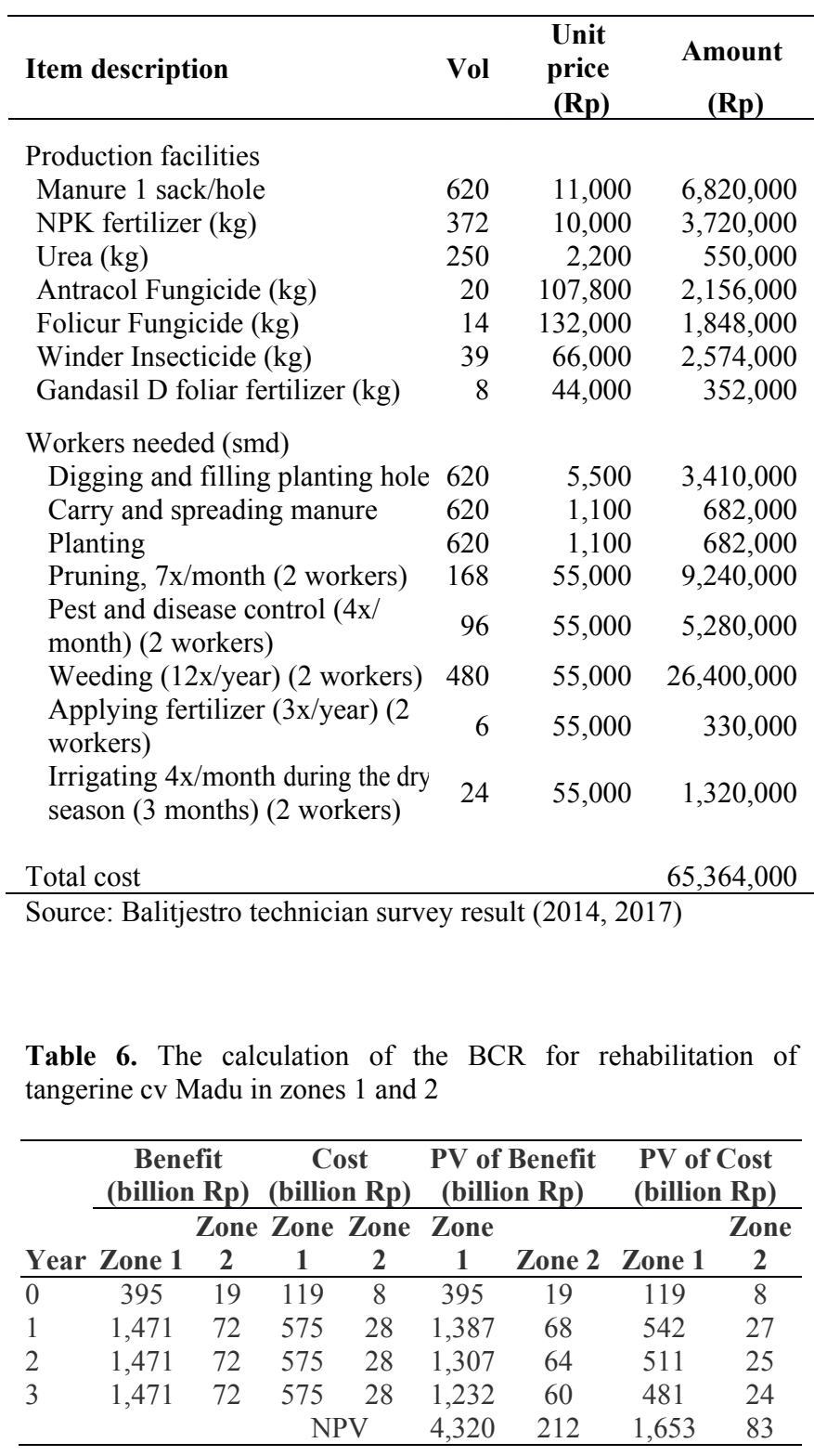

Note: discount factor $=6.10 \%$

BCR for one year BCR zone $1=395 / 118=3.33 \quad$ BCR zone $1=4,320 / 1,653=2.61$ BCR zone $2=19 / 8=2$

BCR zone $1=4,320 / 1,653=2.6$
BCR zone $2=212 / 83=2.57$

Table 7. Calculation of BCR for the opening of the new tangerine cv Madu cultivation land

\begin{tabular}{crrrr}
\hline Year & $\begin{array}{c}\text { Benefit } \\
\text { (billion } \\
\text { Rp) }\end{array}$ & $\begin{array}{c}\text { Cost } \\
\text { (billion } \\
\text { Rp) }\end{array}$ & $\begin{array}{c}\text { PV of Benefit } \\
\text { (billion Rp) }\end{array}$ & $\begin{array}{r}\text { PV of Cost } \\
\text { (billion Rp) }\end{array}$ \\
\hline 0 & 0 & 270 & 0 & 270 \\
1 & 0 & 410 & 0 & 410 \\
2 & 0 & 410 & 0 & 410 \\
3 & 772 & 410 & 646 & 410 \\
& & NPV & 646 & 1,498 \\
\hline
\end{tabular}

Note: discount factor $=6.10 \%$; $\mathrm{BCR}$ for three years; $\mathrm{BCR}=$ $646 / 1498=0.47$
The cost-benefit analysis has been widely used to rationalize public projects because it can give an objective view of the projects in question (Lekh and Virendra 2014). The financial feasibility of the benefit-cost ratio has given a preliminary description that the rehabilitation projects of the tangerine cv Madu in the Karo Regency are recommended to be undertaken with the support and participation from the farmers (Walid et al. 2011; Samuel et al. 2016); though in reality, the government is not doing direct handling. This study is intended as an initial guidance for making decisions, determining the potential benefits to be gained and the losses that could be avoided. This study also gives an overview of the budget that should be prepared. Therefore, this analysis is recommended to be performed by policymakers handling public projects. Even though the results of our research may not apply to commodities other than tangerine that affected by volcanic ash fallout, this study has explained the need for detailed analyses of actions needed to be taken upon such situation.

\section{ACKNOWLEDGEMENTS}

The authors would like to thank Marsono and Haryono of Balitjestro for their technical assistances with the information and guidance on the management of tangerine cv Madu orchard. Our appreciation also goes to Ashari and Abdullah Ibragimov for their valuable input. We would like to express our sincere thanks to the reviewers for the careful reading and insightful comments that help us improve the quality of this paper.

\section{REFERENCES}

Andre C, Delphine B, Helena RV, Benedicte R 2016. Protection by hard defense structures or relocation of assets exposed to coastal risks: contributions and drawbacks of cost-benefit analysis for long-term adaptation choices to climate change. Ocean Coast Manag 134: 173182 .

Asa W, Tobias AG. 2015. New collaborations in daily emergency response: applying cost-benefit analysis to new first response initiatives in the Swedish fire and rescue service. Int J Emerg Serv 4 (2): 177-193.

Bangun T, Lumbaraja P, Tindaon F. 2014. Karakterisasi dan remediasi lahan pertanian pasca erupsi Gunung Sinabung Tanah Karo. Presented in International Alumni Seminar" Climate change in SouthEast Asia: how to manage disaster mitigation and ensure food and nutrition security". Banda Aceh, Medan, 3-11 October 2015 [Indonesian]

BPS [Badan Pusat Statistik]. 2010. National Socio-Economic Survey 2010. Statistics Indonesia (BPS), Jakarta. [Indonesian]

BPS. 2016. BPS Data-Economic and Trade-Foreign trade-Exports and Import (dynamic)-Mandarin - [Time Series (2013-2015)]. Statistics Indonesia (BPS), Jakarta. [Indonesian]

Burnett K, Christopher W, Adele B. 2017. Benefit-cost analysis of watershed conservation on Hawai'i Island. Ecol Econ 131: 262-274.

Craig H, Thomas W, Carol S, Valeria O, Gustavo V, Peter B. 2016. Impacts to agriculture and critical infrastructure in Argentina after ashfall from the 2011 eruption of the Cordon Caulle volcanic complex: an assessment of published damage and function thresholds. J Appl Volcanol 5: 7-38.

Department of Agriculture, Province of North Sumatra. 2014. Progress report of the Sinabung Mountain eruption on food agriculture and horticulture. Dinas Pertanian Propinsi Sumatra Utara, Medan. [Indonesian] 
Djukic M, IIjcho J, Olja MI, Milena L, Dusko B. 2016. Cost-benefit analysis of an infrastructure project and a cost-reflective tariff: A case study for investment in wastewater treatment plant in Serbia. Renew Sustain Energ Rev 59: 1419-1425.

Halicioglu F, Karatas C. 2011. A social discount rate for Turkey. Quality Quantity 47: 1085-1091.

IPB. 2013. Brief Summary of Investment and Business Profile of Archipelago Flower and Fruit. Institut Pertanian Bogor, Bogor. [Indonesian].

Ladaniya MS. 2008. Comercial fresh citrus cultivars and producing countries. In: Ladaniya S (ed.),. Citrus Fruit: Biology, Technology and Evaluation. Academic Press, San Diego, USA.

Lekh S, Virendra. 2014. The cost benefit analysis of providing resilience. Procedia Econ Financ 18: 361-368.

Mechler R. 2016. Reviewing estimates of the economic efficiency of disaster risk management: opportunities and limitations of using riskbased cost-benefit analysis. Nat Hazards 81: 2121-2147.

Moore MA, Boardman AE, Vining AR. 2013. More appropriate discounting: the rate of social time preference and the value of social discount rate. J Benefit-Cost Anal 4: 1-16.

Mufidah L, Fatimah MA, Bach NL, Abdulla I. 2016. The mandarin orange industry in Indonesia: a policy evaluation. Am-Eur J Sustain Agric 10 (5): $10-20$.

Pusdatin. 2015. Pusat Data dan Sistem Informasi Pertanian. Citrus Outlook, Jakarta. [Indonesian]
Salisu I, Uduak A, Monsuru A. 2012. Interventions for mitigating indoorair pollution in Nigeria: a cost-benefit analysis. Intl J Energ Sect Manag 6 (3): 417-429.

Samuel AD, Abdulai E, Edinam DS, Isaac GKA. 2016. Participation and output effect of a Block Farm Credit Programme in selected districts of Northern Ghana. Agric Financ Rev 76 (3): 348-361.

Shreve CM, Kelman I. 2014. Does mitigation save? Reviewing costbenefit analyses of disaster risk reduction. Interl J Disaster Risk Reduct 10: 213-235.

Sugiyatno A, Nainggolan P. 2014. The impact of Sinabung Mountain eruption on citrus plant growth in Karo District, North Sumatra. Proceeding of National Seminary PERHORTI. Malang, 5-7 November 2014. [Indonesian]

Walid EA, Edward A. 2011. Beyond value? Measuring the costs and benefits of public participation. J Integrat Care 19 (6): 45-57.

Wilson T, Cole J, Johnston D, Cronin S, Stewart C, Dantas A. 2012. A short and long-term evacuation ofatple and livestock during a volcanic crisis: lessons from the 1991 eruption of Volcan Hudson, Chile. J Appl Volcan 1 (1): 2.

Zhuang J, Hang Z, Lin T, De Guzman F. 2007. Theory and Practice in the Choice of the Social Discount Rate for Cost-Benefit Analysis: A Survey. ERD working paper, No.94. Asian Development Bank, Bangkok. 